\title{
Mechanical Properties and Microstructure of Aluminium Alloy AW6082-T6 Joints Welded by Double-Sided MIG Process before and after Aging
}

\author{
Saulius BASKUTIS*, Audrius ŽUNDA**, Raimondas KREIVAITIS*** \\ *Kaunas University of Technology, Studentu str. 56, 51424 Kaunas, Lithuania, E-mail: saubask@ktu.lt \\ **Vytautas Magnus University, Studentu str. 11, 53361 Kaunas region, Lithuania, E-mail: audrius.zunda@vdu.lt \\ ***Vytautas Magnus University, Studentu str. 11, 53361 Kaunas region, Lithuania, E-mail: raimondas.kreivaitis@vdu.lt
}

cross $^{\text {ref }}$ http://dx.doi.org/10.5755/j01.mech.25.2.22008

\section{Introduction}

Most aluminium alloys are malleable, ductile, lightweight, enabling them to be manufactured in a variety of ways such as extrusion, stamping, hot and cold rolling, pressing, forging, bending, etc. Furthermore, many of aluminium alloys can be readily welded. Lightweight aluminium alloy structures (especially thin-walled) are often welded using specialized methods, such as friction stir welding (FSW) or bifocal hybrid laser welding (BHLW) and other techniques. For larger structures inert gas shielded processes, such as metal inert gas arc welding (MIG) or tungsten inert gas arc welding (TIG) are more commonly used. MIG welding is very popular in the field of nonferrous metal welding [1]. Today's pulsed MIG technology enables welders to easily create weld beads of just the right size to eliminate excess heat input, over-welding which influence the quality of the weld seam. The pulsed MIG welding uses relatively low background current, therefore the current is insufficient to melt the fillet rod but the pulse of high current melts the filler metal and projects this as a spray of droplets giving excellent metal transfer enabling to give desirable weldment at low average welding currents [2].

6082-T6 aluminium alloy belongs to Al-Mg-Si series alloys, is a medium strength alloy with excellent corrosion resistance, highest strength of the $6 \mathrm{xxx}$ series alloys and widely used in welded structures. Furthermore, the magnesium silicide $\left(\mathrm{Mg}_{2} \mathrm{Si}\right)$ provides ability to become alloy heat treated for improved strength. In the various works, the general tendency is quite clear that the properties of a mechanical joint after welding in one way or another depend on the welding modes and the initial properties of the material [3-6].

Many welded aluminium alloys, including the AW6082-T6 alloy, tend to produce hot cracks, especially if the welding procedures are not carefully controlled. It has been observed that $\mathrm{Mg}$ and $\mathrm{Si}$ increases the susceptibility of the alloy to hot cracking and that the concentration of $\mathrm{Mg}$ and $\mathrm{Si}$ is often higher near the cracks [4, 7]. Studies also show that the structure of the extruded aluminium alloy 6082 , aged in a salt bath at $620^{\circ} \mathrm{C}$, has a lower degree of recrystallization of grain growth and that $\mathrm{Mg}$ and $\mathrm{Si}$ concentrations are higher at the grain boundaries [8]. Furthermore, one of the most severe problems in welding aluminium alloys is the development of hydrogen gas porosity during solidification [9]. Hydrogen gas porosity occurs as the dissolved hydrogen cannot escape during solidification. The results of many hardness tests show that, when welding with TIG, MIG technology, the heat affected zone (HAZ) area hardness is usually higher than the center of the seam, but closer to the base metal (BM), possibly due to annealing, the hardness reaches the value of the fusion zone (FZ) [3, 4]. The fracture morphology and the microhardness distribution of double-pass joint have been examined by $\mathrm{Li}$ et. al. [10]. It was determined that the lowest hardness is in the fusion zone and the weak region of the welded joint was partly melted zone (PMZ) near the front toe. In order to decrease the heat effect on the microstructure of the PMZ, the heat input of the second pass should be decreased while the energy density should be increased. In order to avoid the influence of the heat of the second pass on the mechanical parameters of the first pass weld, Feng et. al. [11] used two industrial robots in his research to make the weld on both sides simultaneously. The effects of welding speed and power on weld geometry by double sided arc welding of aluminium alloy sheet was studied by Kwon and Weckman [12]. It was stated that there were no significant changes in hardness of the BM, HAZ and weld metal. A comparison of microhardness testing results in two-pass and single-pass laser welded samples was done by Harooni et. al. [13]. The results showed that two-pass welded samples had a higher hardness due to grain refinement since the grains were undergone two periods melting and solidification. Yi et. al. [14] described the effect of current on the morphology of $\mathrm{Al}$ alloy in double-pulsed metal inert gas welding process. The results demonstrated that the welding bead width and depth of the joint increase with increasing the average current. Mechanical properties of the butt joints using MIG/TIG double-side arc welding have been investigated by Zhang et. al. [15]. The testing results showed that weld formation, especially the formation of back weld due to double-side arc welding, was improved obviously. Experiments carried out by Ye et. al. [16, 17] proved that excellent weld appearance was achieved by double-sided welding-brazing at a lower welding input. Aging influence on hardness of 6082-T6 aluminium alloy was investigated by Prabhukhot and Prasad [18]. The results showed that heat treatment and artificial aging process are responsible for change in hardness of alloy.

However, although considerably studies have been reported in published literature about double-pass welding and artificial or natural aging, studies on microhardness and microstructure changes after the second pass and after long-time natural aging still appears not exhaust- 
ively documented. Therefore, in this study the influence of the second pass welding on the microhardness and microstructure of the first pass welding has been analysed.

\section{Materials and experimental equipment}

The base material used in this work is AW6082 aluminium alloy in the form of $10 \mathrm{~mm}$ thick plates in $\mathrm{T} 6$ condition. AW6082-T6 aluminium alloy must be welded with care, because with less than $1 \% \mathrm{Mg}$ and $1 \% \mathrm{Si}$, it has a turn to crack, particularly in the HAZ due to relatively high heat input. This phenomenon is known as liquation cracking. To avoid cracking mechanism in the HAZ, 6xxxx series aluminium alloys require a MIG filler metal containing $5 \% \mathrm{Mg}$. Therefore, as a filler rod aluminium welding wire ER5356 with a diameter of $1.00 \mathrm{~mm}$ containing approximately $5 \%$ of $\mathrm{Mg}$ was chosen for the welding. The chemical compositions of the base material and filler rod are reported in Table 1.

Chemical composition of aluminium alloy AW6082-T6 and filler metal

Table 1

\begin{tabular}{|c|c|c|c|c|c|c|c|c|c|}
\hline \multirow{2}{*}{ Material } & \multicolumn{9}{|c|}{ Components, \% } \\
\cline { 2 - 10 } & $\mathrm{Si}$ & $\mathrm{Fe} \max$ & $\mathrm{Cu} \max$ & $\mathrm{Mn}$ & $\mathrm{Mg}$ & $\mathrm{Cr} \max$ & $\mathrm{Zn} \max$ & $\mathrm{Ti} \max$ & $\mathrm{Al}$ \\
\hline Base metal AW6082-T6 & $0.7-1.3$ & 0.5 & 0.1 & $0.4-1.0$ & $0.6-1.2$ & 0.25 & 0.2 & 0.1 & bal. \\
\hline Filler rod ER5356 & 0.25 & 0.4 & 0.1 & $0.05-0.2$ & $4.5-5.5$ & $0.05-0.2$ & 0.1 & $0.06-0.2$ & bal. \\
\hline
\end{tabular}

Compared to the ER4043 filler rod, which is also used for AW6082 aluminium alloys welding, the ER5356 metal has higher ductility, higher crack sensitivity, higher shear strength, higher tensile and lower penetration. The plates of AW6082-T6 aluminium alloy have been cut into the sizes of $200 \times 100 \times 10 \mathrm{~mm}$. Double-V butt joint configurations (Figs. 1 and 2) have been done to prepare welded joints.

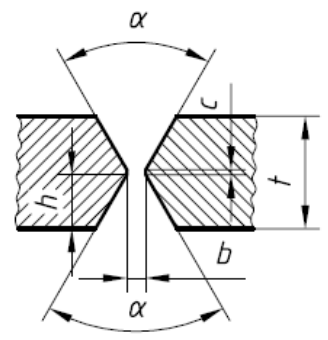

Fig. 1 Configuration of double $-\mathrm{V}$ butt welding joint: $b \leq 3$ $\mathrm{mm}, \alpha \geq 60^{\circ}, 6 \leq t \leq 15 \mathrm{~mm}, c \leq 2 \mathrm{~mm}$

The preparation of the plates for welding has been accomplished according to the standard BS EN ISO 96923:2001 [19].
Pulsed MIG welding technology was chosen since it is suitable for both thin and thick plates due to modified spray transfer process. Modular MIG/MAG inverter welding machine Phoenix 355 Progress Pulls TDM with separate wire feeder was used to produce double-sided butt weld joints.

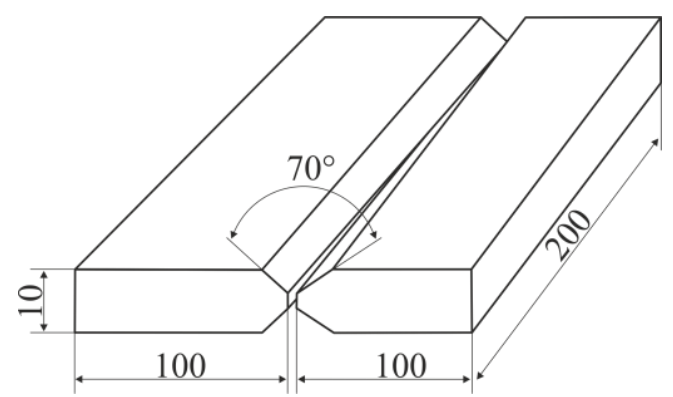

Fig. 2 Dimensions of double $-\mathrm{V}$ butt joint plates

Pre-welding grinding and chemical cleaning with acetone has been done before the welding. The main parameters of welding are listen in Table 2.

Main parameters of welding

\begin{tabular}{|c|c|c|c|c|c|c|}
\hline $\begin{array}{l}\text { No of weld- } \\
\text { ing mode }\end{array}$ & $\begin{array}{l}\text { MIG welding } \\
\text { current, A }\end{array}$ & $\begin{array}{l}\text { MIG welding } \\
\text { voltage, } \mathrm{V}\end{array}$ & Groove angle, ${ }^{\circ}$ & $\begin{array}{c}\text { Welding speed, } \\
\mathrm{mm} / \mathrm{min}\end{array}$ & $\begin{array}{c}\text { Filler rod } \\
\text { speed, } \mathrm{m} / \mathrm{min}\end{array}$ & $\begin{array}{c}\text { Heat input, } \\
\mathrm{kJ} / \mathrm{mm}\end{array}$ \\
\hline $1-1^{*}$ & 135 & 13 & \multirow{8}{*}{70} & 343 & 11.4 & 0.24 \\
\hline $2-1$ & 150 & 14 & & 372 & 12.9 & 0.27 \\
\hline $3-1$ & 165 & 15 & & 425 & 14.4 & 0.28 \\
\hline $4-1$ & 180 & 17 & & 485 & 15.8 & 0.30 \\
\hline $1-2$ & 135 & 13 & & 343 & 11.4 & 0.24 \\
\hline $2-2$ & 150 & 14 & & 372 & 12.9 & 0.27 \\
\hline $3-2$ & 165 & 15 & & 425 & 14.4 & 0.28 \\
\hline $4-2$ & 180 & 17 & & 485 & 15.8 & 0.30 \\
\hline
\end{tabular}

*the first number indicates the test number and the welding parameters, the second is the seam number

The weld pool, as well as the electrode was protected from the atmosphere, so the argon was used as shielding gas and flow rate was $18 \mathrm{l} / \mathrm{min}$. After welding standard cutting, mechanical polishing and etching procedures have been used to prepare cross-sectional macrographs. Grinding was done with $\mathrm{SiC}$ water-cooled paper and polishing with 9,3 and $1-\mu \mathrm{m}$ diamond emulsion on a Trident polishing cloth. For this purpose, grinding and polishing machine Tegramin 20 (Struers A/S) was used.
Etching has been performed by Flick's chemical reagent (2 ml HF (48\%), $3 \mathrm{ml} \mathrm{HCl}$ (conc.), $195 \mathrm{ml} \mathrm{H} \mathrm{H}_{2} \mathrm{O}$. Specimens' etching has been done at room temperature until the required contrast was reached whereas deposits were removed with $\mathrm{HNO}_{3}$ then washed in warm water and dried.

Vickers microhardness tests have been conducted on CSM microhardness indentation tester with a $50 \mathrm{~g}$ load. Microhardness measurements were carried out at $3 \mathrm{~mm}$ depth from the face and root side of each cross section of 
the welds. A constant strain rate setting $1 / P(d P / d t)$ of $2 \mathrm{~min}^{-1}$ and a pause of $10 \mathrm{~s}$ has been set at maximum load. Microstructures of the joints have been analysed using optical microscope Nicon Eclipse E1000 with magnification from $\times 50$ to $x 1000$ and scanning electron microscope (SEM). The Everhart-Thornley detector (ETD) and blackscattered electron detector (BSE) were used in SEM.

\section{Results and discussion}

The weld material zone was a mixture consisting of melted base metal and 5356 filler rod with an as-cast dendritic cell structure. It is known that $6 \mathrm{xxxx}$ aluminium alloys have strong over-aging tendency during welding, especially in fully aged condition (T6) [20]. During welding the adjacent metal to the fusion zone (FZ) is exposed to heat and the heat affected zone (HAZ) as isothermal zone can be divided into two subzones (Fig.3). The zone of higher temperature near to weld pool, called partially melted zone (PMZ), is approached by solubilisation maintaining that the cooling rate is high. In PMZ the microstructure of the material will tend to age in natural manner. By decreasing the temperature toward the base metal (BM), the second subzone appears that it is called as over-aging zone (OAZ). OAZ as the lower temperature zone near to the BM is exposed to various temperatures where the aging phenomena and over-aging occurs. In the case of HAZ, the resulting temperature is between two well defined temperatures, i.e. the artificial aging temperature of the alloy and the melting temperature of the alloy. Due to the thermodynamic instability of the precipitates, a microstructural transformation occurs. The famous reaction that take place in second subzone of the Al-Mg-Si alloy is where the overaging in the HAZ is produced by the transformation of semi coherent needles $\beta$ " (needle shape) precipitates into rods $\beta^{\prime}$ (rod shape) precipitates [21, 22].

$6 \times x \times x$ aluminium alloys are heat treatable because of a phenomenon called precipitation hardening. Heat treated aluminium alloys do not harden due to martensitic transformation, like steel does. In precipitation hardening of aluminium alloys, one metal can be dissolved in another and solubility generally increases with heat input and considerably reduces at lower temperatures. Combinations of magnesium and silicon dissolve in 6xxxx aluminium as it is heated.

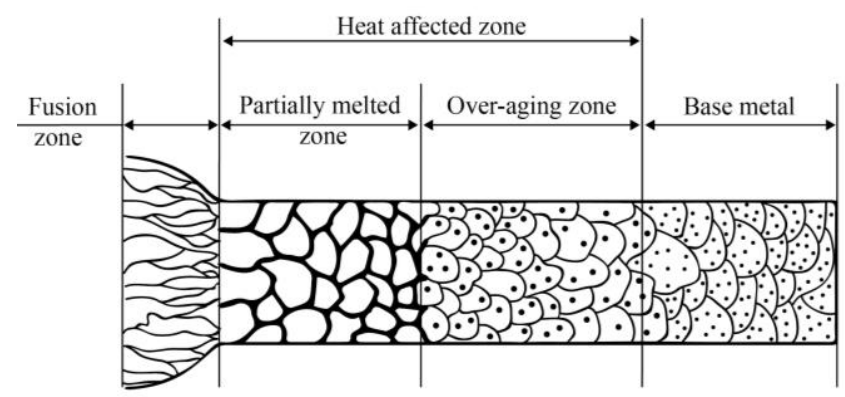

Fig. 3 Schematic representation of the microstructural changes of the welded joint zones

The HAZ of welds in heat treated alloys differs significantly from non-heat treatable alloys. In the heat treated alloys the strength of the HAZ can be significantly weaker if excessive heat input is used. It is very important carefully control the temperature of the weld between weld passes, not to use excessive preheating, and to avoid wide weave passes which will result in too much heat input.

\subsection{Analysis of microstructure}

The microstructure of the seam zone after MIG welding traditionally has a specific structure. As in the case of many alloys, it consists of well-developed columnar structures, which grew epitaxial from the solid-liquid boundary or PMZ grains (Fig. 4, white arrows) along the fusion boundary up to the surface. In addition, the structure of the transition deep from the surface is different. Analysing the images made by the optical microscope of the alloy AW6082-T6 seams, the microstructure of the long, centred towards the seam surface oriented grain has been observed (Fig. 4, seam area). Fig. 4, a shows a new weld seam (NS) and Fig. 4, b shows the old seam (OS) after one year of natural aging.

It has been noticed that the structure looks like layered (the boundaries of the layers in Fig. 4 are shown in black arrows). Moreover, the pores are clearly visible in the structure (Fig. 4). Such a structure is typical for all investigated welded joints under different welding current. Also, it has been observed that in all cases in the FZ there are different sizes of porosity. When welding in lower modes $(135,150 \mathrm{~A})$ the pores are larger and closer to the seam surface, while welding in higher mode (165, $180 \mathrm{~A})$, the pores are smaller and closer to the root of the seam.

By analysing SEM images, it can be seen that the structure of FZ is abundant in various shapes and sizes of grains. Often small grains are predominant, which form line cluster structures, and also occur in dendrites formations (Fig. 6, a). In the HAZ predominates irregularly shaped grains (Fig. 5, a). The white spots visible on SEM $\mathrm{BSE}$ are $\mathrm{Mn}_{12} \mathrm{Si}_{7} \mathrm{Al}_{5}$ grains. Black grains are pure aluminium inserts in the matrix and micropores. The fine-grained clusters (Fig. 6, a) or dendritic structure (Fig. 5, a) is clearly visible in the FZ, and the fragments of porosity is visible in the FZ under welding with higher energy (Fig. 6, b). Increasing the welding current increases the temperature of the weld pool and thus increases the hydrogen absorption rate of molten metal. Visible different intensities of gray zones - grains of different concentrations of $\mathrm{Al}$ solid solution (Fig. 5 and 6, b).

In addition, it can be noted that when higher energy was applied, the size of these zones decreased. Greater $\mathrm{Mn}_{12} \mathrm{Si}_{7} \mathrm{Al}_{5}$ or $\mathrm{Mg}_{2} \mathrm{Si}$ intermetallic grains, which are characteristic of the BM and HAZ, have not been observed in the FZ.

Non-metallic impurities and cracks can be observed in the structure, but they are very negligible. Beside long transverse cracks, many short microcracks were observed a little apart from the PMZ. The reason of these cracks is likely to be due to $\mathrm{Mg}$ diffusing from the weld reinforcement above the cracked area into the HAZ. More detailed seam structure changes in aging studies are planned in the future. However, it can now be stated that the effect of re-heating (aging) can be seen in the structure of the observation of the boundaries of the so-called layers: in the old seams, boundaries of the layers are widespread, or they are not clearly expressed (Fig. 4, b). 


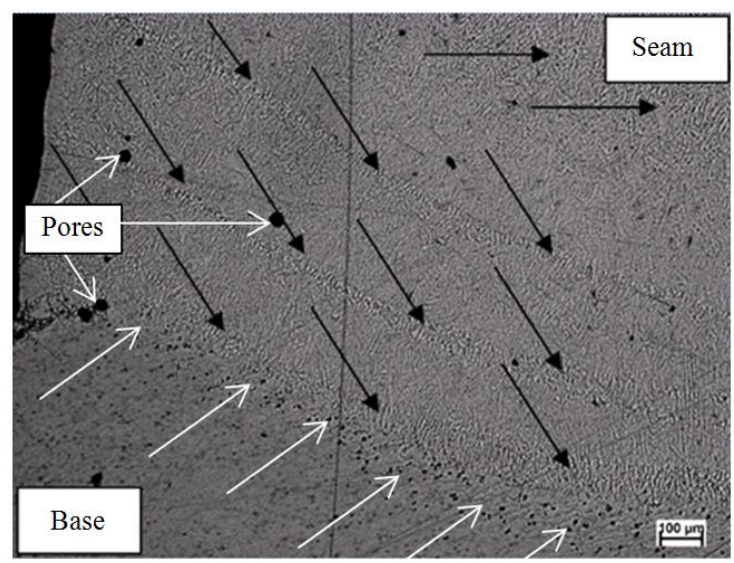

a

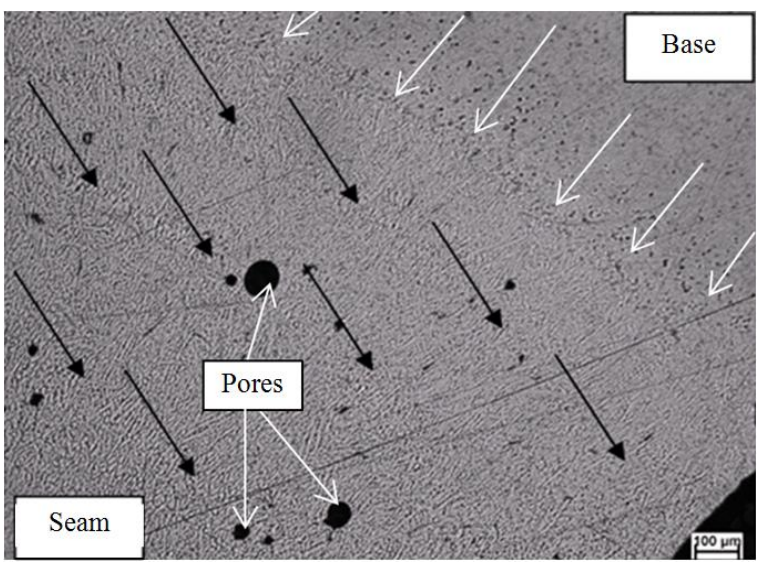

b

Fig. 4 Microstructure of the welded joint (optical images, x50) under welding current $135 \mathrm{~A}: \mathrm{a}-\mathrm{NS}, \mathrm{b}-\mathrm{OS}$

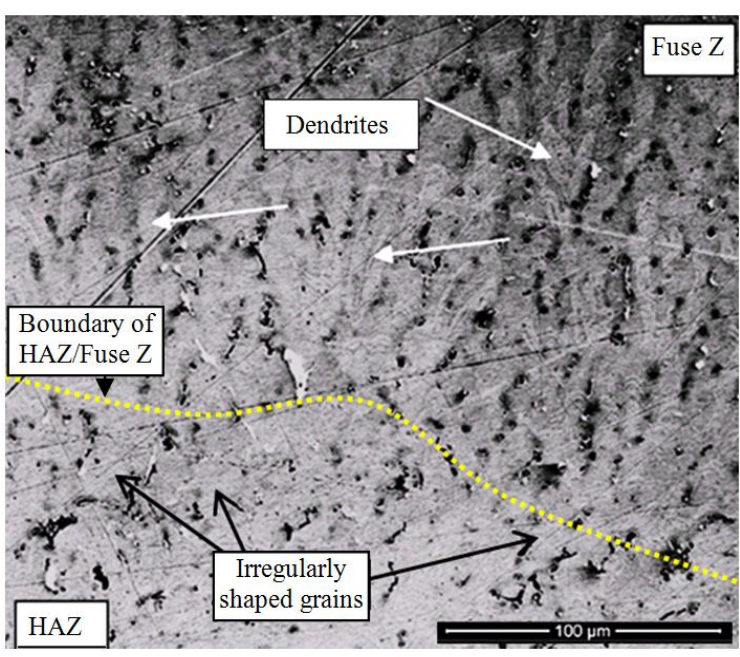

a

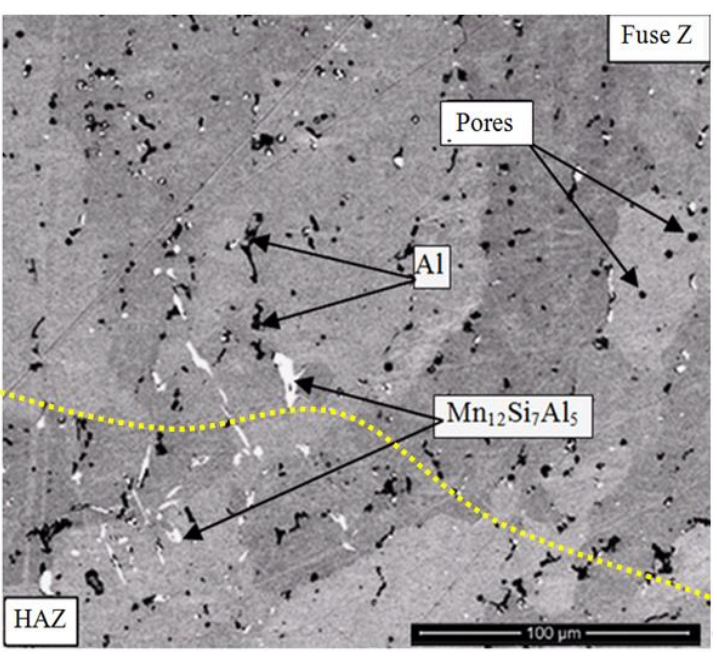

b

Fig. 5 Microstructure of the HAZ of the welded joint (SEM images, x1200) under welding current 135 A: a - SEM with ETD, b-SEM with BSE

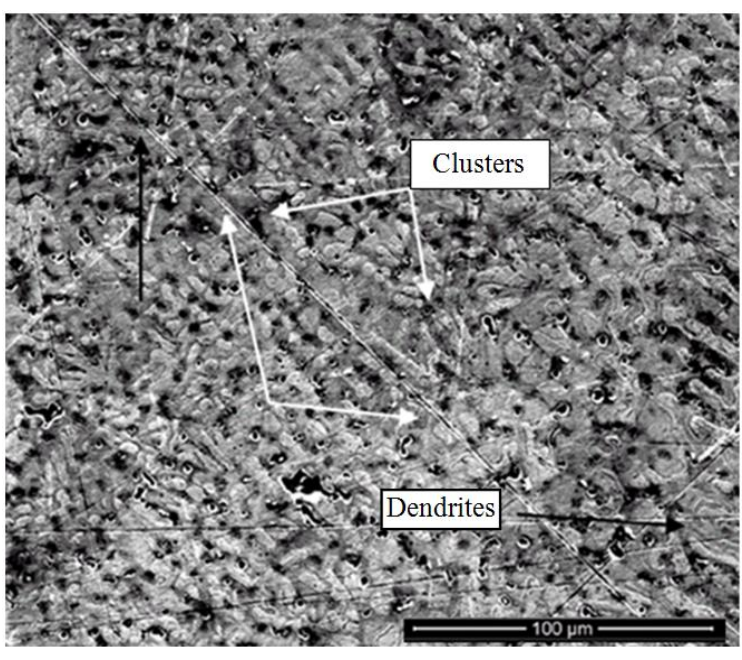

a

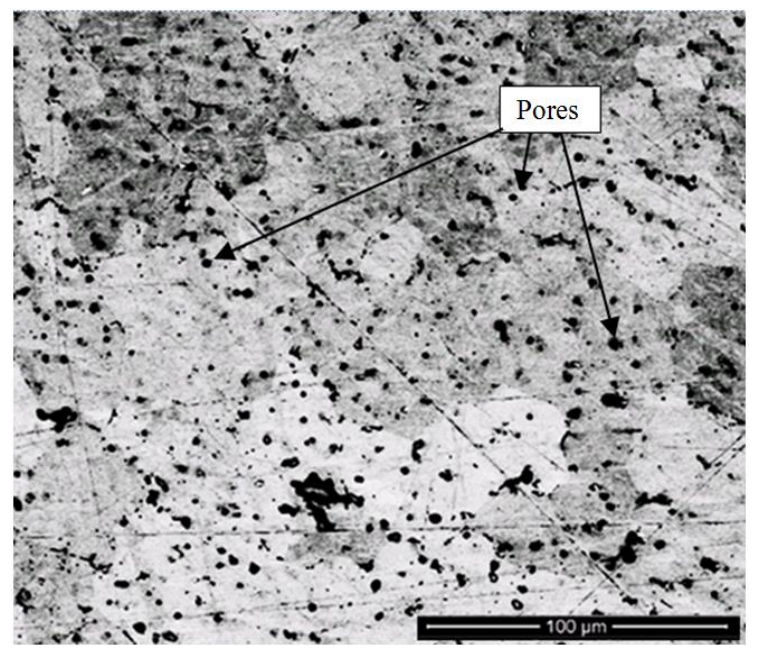

b

Fig. 6 Microstructure of the FZ of the welded joint (SEM images, x1200) under welding current 180 A: a - SEM with ETD, b - SEM with BSE

\subsection{Hardness measurements}

After the welding the first seam in each of the welding modes the specimens were cut at perpendicular direction into the segments and samples were made for microhardness examination. Microhardness was measured according to the scheme shown in Fig. 7, a. The distance between the measuring points is $0.3-0.5 \mathrm{~mm}$, and the distance between lines is $0.3 \mathrm{~mm}$. When the seam was welded on the second side of double $-\mathrm{V}$ butt joint plates, 
specimens were also cut out and samples were made for microhardness tests. Microhardness was measured according to the scheme shown in Fig. 7, b.

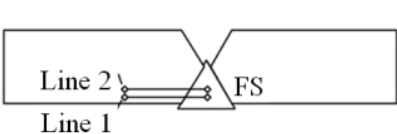

a

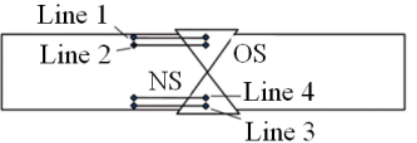

b
Fig. 7 Diagram of microhardness measurement, where FS - first seam, OS - old seam and NS - new seam: a for first welded seam, b) for new welded seam

For double-side seam samples microhardness measurements were repeated after a year according to the scheme shown in Fig. 7, b. The results of the microhardness examination showed that in all cases reheating during the welding of the second seam affected more or less the hardness of the HAZ of the first weld.

In the $\mathrm{BM}$ structure the $\mathrm{Mg}_{2} \mathrm{Si}$ precipitates, 6082 Al solid solution and $\mathrm{Mn}_{12} \mathrm{Si}_{7} \mathrm{Al}_{5}$ precipitates are dominated [23]. During the welding process, under the influence of temperature, intermetallic mixtures are split into petty factions and mixed. Part of them recovers under artificial or natural aging. Due to reversion of $\mathrm{Mg}_{2} \mathrm{Si}$ precipitates present in aluminium matrix, in all cases the hardness decreases in HAZ. In the HAZ zone, hardness is highest in the PMZ, because this zone has fine grains compared the FZ. A significant difference for the microhardness of FZ and HAZ with respect to BM has been observed during the measurement of the first seam (FS) (Fig. 8, a - 9, a). This is
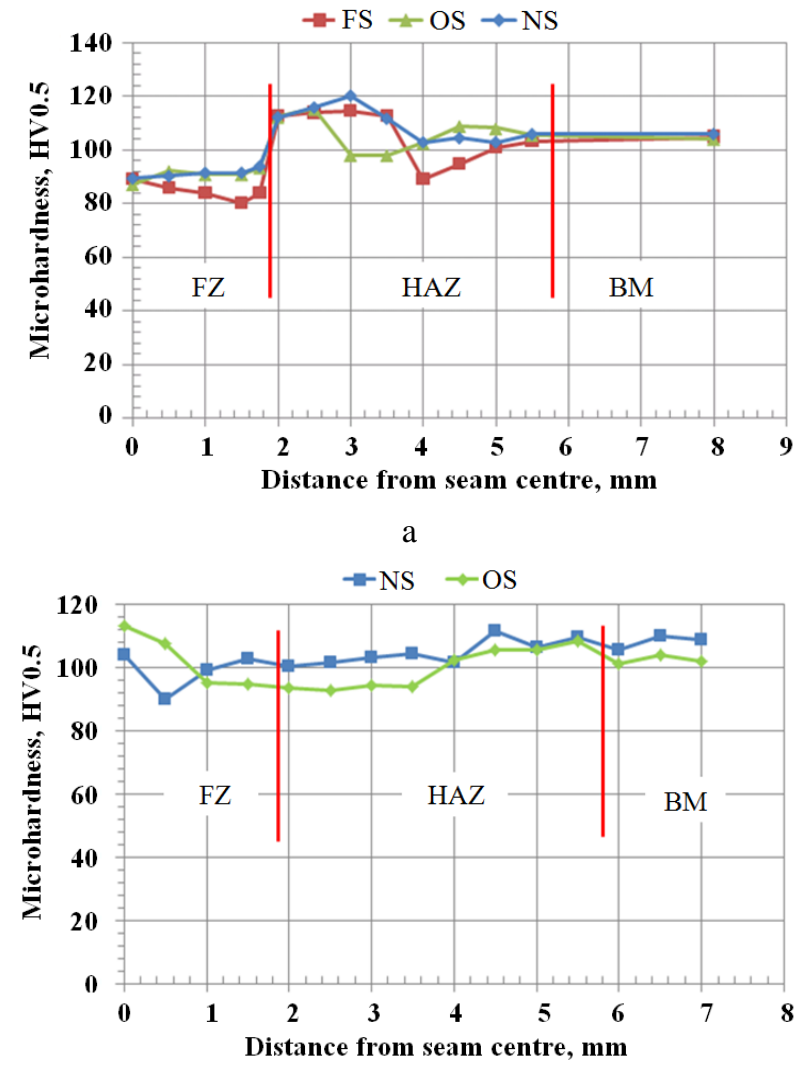

b

Fig. 8 Microhardness distribution on the cross-section of joint under welding current $135 \mathrm{~A}$, where FS - first seam, OS - old seam and NS - new seam: a- before aging, $b$ - after one year of natural aging due to the fact that HAZ is closer to the BM, the temperature is lower and it is not sufficient for partial phase transition. Closer to the FZ, the temperature is sufficient, which leads to partial dissolution of fine precipitates.

Analysis of microstructures showed that the concentration of the fine precipitation is more in BM than that in HAZ. This indicates that mechanical properties of different zones after welding will be different.

It can be noted that under welding current $135 \mathrm{~A}$ (Fig. 8, a) and $150 \mathrm{~A}$, the change in microhardness between FS (first single sided seam) and OS (the same seam FS only after the second seam NS is welded) positive, i.e. hardness increased. Whereas, in the case of $165 \mathrm{~A}$ and 180 A (Fig. 9, a), the FS hardness in point of OS has decreased. Furthermore, it can be concluded that increasing the welding current, the width of the FZ increases, while the HAZ decreases. Hence, heat treatment causes reduction in hardness. This is confirmed by the fact that the softened area was formed in the fusion zone because the precipitates disappeared due to welding heat input.

Interestingly, after repeating microhardness tests after a year of natural aging, it has been observed that the hardness increase in the HAZ zone has disappeared (Fig. 8, b - 9, b). Hence, aging time, as well as heat treatment, affects the hardness decrease. At longer ageing time precipitates start to coarsen and strengthening effect decreases.

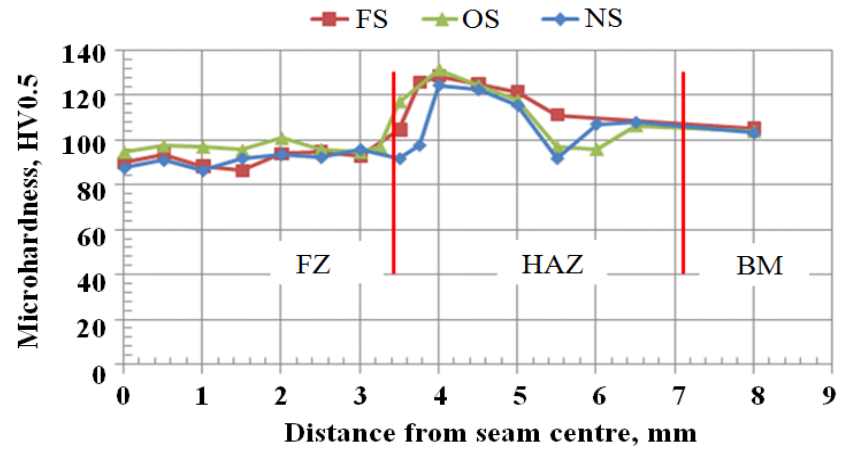

a

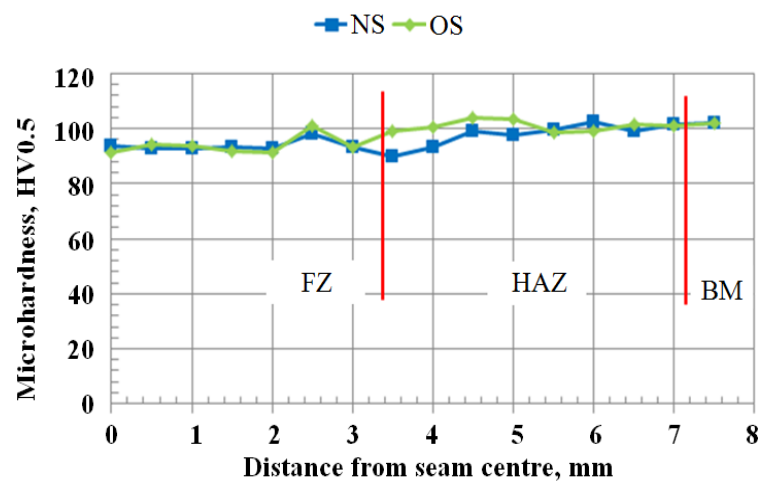

b

Fig. 9 Microhardness distribution on the cross-section of joint under welding current $180 \mathrm{~A}$, where FS - first seam, OS - old seam and NS - new seam: a- before aging, b- after one year of natural aging

\section{Conclusions}

The microstructural properties and microhardness distributions examining of zones of the welded joints have 
been studied in the present research. Following conclusions can be drawn.

1. This study suggests that care must be taking in using welding current because it is the one of the most influential parameters on the size and distribution of the precipitates and also on weld pool geometry, HAZ dimensions and herewith microhardness of the welded joint zones.

2. From research result is obvious that the reduction of microhardness was caused by the structural instability due to coarsening and over-ageing of the precipitates in HAZ. The area of HAZ close to the fusion zone, known as PMZ is harder than the rest of the HAZ. The area of HAZ close to the base is softer than the rest of the HAZ or BM due to the fact that welded seam is under the impact of relatively high temperature and rapid cooling rate.

3. Summarizing the results, it can be stated that the artificial aging of the AW6082-T6 double-sided joints, in the first welded seam after the welding of the opposite side seam takes place. This affects the structure and microhardness of the HAZ of the first seam. The influence of natural long-term aging on the recovery process of the hardness of AW6082-T6 alloy seam is evident.

4. What exactly is the effect of long-term aging on the structure of the seam according to the data of this study is difficult to evaluate. These answers are still under investigation.

\section{References}

1. Liu, L. Welding and joining of magnesium alloys. 2010. Woodhead Publishing Ltd., Cambridge, England, $388 \mathrm{p}$.

2. Mathers, G. 2002. The welding of aluminium and its alloys. Woodhead Publishing Ltd., Cambridge, England, $236 \mathrm{p}$.

3. Walter, V.; Weidenmann, A.; Schulze, V. 2014. A comparison of FSW, BHLW and TIG joints for Al-Si$\mathrm{Mg}$ alloy (EN AW-6082 T6), Procedia CIRP, 18(2014): 120-125.

https://doi.org/10.1016/j.procir.2014.06.118.

4. Miyazaki, M.; Nishio, K.; Katon, M.; Mukae, S.; Kerr, H. W. 1990. Quantitative investigation of heataffected zone cracking in aluminium alloy A6061, Welding Research supplement, September 1990: 362-s - 372-s.

5. Kolarik, L.; Kolarikova, M.; Kovanda, K.; Vondrous, P.; Dunovsky, J. 2012. Influence of repair welding on weld quality of Al alloy EN AW 6082-T6, Metal, $21^{\text {st }}$ Int. Conf. on Metallurgy and Materials 2325.5.2012, Brno, Czech Republic: 1-7.

6. Zhang, Y. M.; Pan, C.; Male, A. T. 2000. Improved microstructure and properties of 6061 aluminum alloy weldments using a double-sided arc welding process, Metallurgical and Materials Transactions A, 31A: 2537-2543.

7. Kah, P.; Martikainen, J.; Hiltunen, E.; Brhane, F.; Karkhin, V. 2011. Hot cracking susceptibility of wrought 6005 and 6082 aluminum alloys, Hot Cracking Phenomena in Weld III, J. Lippold et al. (eds.), Springer-Verlag Berlin Heidelberg https://doi.org/10.1007/978-3-642-16864-2_4.

8. Lin, C-W.; Hung, F.Y.; Lui, T-S. 2018. Microstructure evolution and microstructural characteristics of Al-
Mg-Si aluminium alloys fabricated by a modified strain-induced melting activation process, Metals 8(1), 3:1-15 https://doi.org/10.3390/met8010003.

9. Luijendijk, T. 2000. Welding of dissimilar aluminium alloys, J. of Materials Processing Technology 103:2935.

10. Li, Q.; Wu, A.; Zhao, Y.; Wang, G.; Yan, D.; Wu, H. 2015. Fracture behavior of double-pass TIG welded 2219-T8 aluminum alloy joints under traverse tensile test, Trans. of Nonferrous Metals Society of China 25:1794-1803.

https://doi.org/10.1016/S1003-6326(15)63785-2.

11. Feng, Y.; Chen, J.; Qiang, W.; Wang, K. 2016. Microstructure and mechanical properties of aluminium alloy 7A52 thick plates welded by robotic double-sided coaxial GTAW process, Materials Science \& Engineering A673: 8-15. http://dx.doi.org/10.1016/j.msea.2016.07.011.

12. Kwon, Y.; Weckman, D. C. 2008. Double sided arc welding of AA5182 aluminium alloy sheet, Science and Technology of Welding and Joining 13(6): 485495.

http://dx.doi.org/10.1179/174329308X271715.

13. Harooni, M.; Ma, J.; Carlson, B.; Kovacevic, R. 2015. Two-pass laser welding of AZ31B magnesium alloy, Journal of Materials Processing Technology 216:114-122.

https://doi.org/10.1016/j.jmatprotec.2014.08.028.

14. Yi, J.; Cao, S.; Li, L.; Guo, P.; Liu, K. Effect of welding current on morphology and microstructure of 2015. Effect of welding current on morphology and microstructure of $\mathrm{Al}$ alloy $\mathrm{T}$-joint in double-pulsed MIG welding, Trans. of Nonferrous Metals Society of China 25:3204-3211.

https://doi.org/10.1016/S1003-6326(15)63953-X.

15.Zhang, Y.; Huang, J.; Ye, Z.; Cheng, Z. 2017. An investigation on butt joints of Ti6Al4V and 5A06 using MIG/TIG double-side arc welding-brazing, J. of Manufacturing Processes 27:221-225.

http://dx.doi.org/10.1016/j.jmapro.2017.05.010.

16. Ye, Z.; Huang, J.; Cheng, Z.; Gao, W.; Zhang, Y.; Chen, S.; Yang, J. 2017. Microstructure and mechanical properties of 5052 aluminum alloy/mild steel butt joint achieved by MIG/TIG double-sided arc weldingbrazing, Materials and Design 1213:69-79.

http://dx.doi.org/10.1016/j.matdes.2017.03.039.

17. Ye, Z.; Huang, J.; Gao, W.; Zhang, Y.; Cheng, Z.; Chen, S.; Yang, J. 2017. Combined effects of MIG and TIG arcs on weld appearance and interface properties in $\mathrm{Al} /$ steel double-sided butt welding-brazing, J. of Materials Processing Tech. 250:25-34. htpp://dx.doi.org/10.1016/j.matprotec.2017.07.003.

18. Prabhukhot, A. R.; Prasad K. 2015. Effect of heat treatment on hardness of 6082-T6 aluminium alloy, Int. J. of Scientific and Engineering Research, 6(12):38-42.

19. BS EN ISO 9692-3:2001. 2001. Welding and allied processes - Recommendations for joint preparation. Part 3: Metal inert gas welding and tungsten inert gas welding of aluminium and its alloys. British Standard Institution, London, $20 \mathrm{p}$.

20. Ambriz, R. R.; Jaramillo, D. 2014. Mechanical behaviour of precipitation hardened aluminium alloys 
welds, Light metal alloys applications, Waldemar A. Monteiro (ed.), InTech, p. 35-59.

http://dx.doi.org/10.5772/58418.

21. Gupta, A. K.; Lloyd, D. J.; Court, S. A. 2001. Precipitation hardening in Al-Mg-Si alloys with and without excess Si, Materials Science and Engineering A316:1117. https://doi.org/10.1016/S0921-5093(01)01247-3,

22. Fadaeifard, F.; Matori, K. A.; Garavi, F.; Al-Falahi, M.; Sarrigani, G. V. 2016. Effect of post weld heat treatment on microstructure and mechanical properties of gas tungsten arc welded AA6061-T6 alloy, Trans. of Nonferrous Metals Society of China 26:3102-3114. https://doi.org/10.1016/S1003-6326(16)64442-,4

23. Kumar, R.; Dilthey, U.; Dwivedi, D. K.; Ghosh, P. K. 2009. Thin sheet welding of Al 6082 alloy by AC pulse-GMA and AC wave pulse-GMA welding, Materials and Design 30: 306-313.

https://doi.org/10.1016/j.matdes.2008.04.073.
S. Baskutis, A. Žunda, R. Kreivaitis

MECHANICAL PROPERTIES AND MICROSTRUCTURE OF ALUMINIUM ALLOY AW6082-T6 JOIUNTS WELDED BY DOUBLE-SIDED MIG PROCESS BEFORE AND AFTER AGING

S u m m a r y

This study focuses on welding of AW6082-T6 aluminium alloy and investigation of the microhardness and microstructure properties in the heat affected and fusion zones using pulsed inert gas arc welding. The effect of welding current on microstructure and solidification variables of the double-sided welds has been studied. The microhardness analysis of the welded joints has been carried out to evaluate the effect of microstructural variations of the weld seam zones. A comparison research on the microhardness and microstructure of opposite sides of the weld after natural aging is presented. The results indicate that the influence of natural long-term aging on the microhardness of the weld seam zones is evident.

Keywords: double-sided welding, aluminium alloy, microhardness, microstructure, aging.

Received November 05, 2018 Accepted April 25, 2019 